\title{
EFFECT OF INTRATRACHEAL ADMINISTRATION OF IOPAMIDOL ON THE ULTRASTRUCTURE OF THE EPITHELIUM OF TERMINAL BRONCHIOLES IN RABBITS (Oryctolagus cuniculus var. edulis)
}

\author{
J. UHLIK ${ }^{1}$, S. TƯMA ${ }^{2}$ \\ ${ }^{1}$ Institute of Histology and Embryology and ${ }^{2}$ Clinic of Radiological Techniques, 2nd Medical Faculty, Charles \\ University, Prague, Czech Republic \\ Received March 11, 1998 \\ Accepted June 5, 1998
}

\begin{abstract}
Uhlík J., S. Tủma: Effect of Intratracheal Administration of Iopamidol on the Ultrastructure of the Epithelium of Terminal Bronchioles in Rabbits (Oryctolagus cuniculus var. edulis). Acta vet. Brno 1998, 67: 97-101.

The ultrastructure of the epithelium of terminal bronchioles in rabbits was studied 40 minutes after intratracheal administration of iodinated water-soluble non-ionic contrast agent iopamidol. The signs of pathological alteration of the epithelial cells may be a result of the transitional hypoxia during administration. The secretory Clara cells were not stimulated to release their secretion, nor the signs of epithelial cells' proliferation were noticed.
\end{abstract}

Terminal bronchioles, rabbit, ultrastructure, contrast agents, tracheobronchography

In spite of an extensive development of non-invasive radiological techniques, the tracheobronchography remains irreplaceable diagnostic method visualising the airways. In our previous study, we aimed at finding the most suitable contrast agent from the morphological point of view evaluating the degree of damage to the airway epithelium. In experiment, the ultrastructure of the epithelium of large extrapulmonary airways was thoroughly studied shortly after intratracheal administration of three iodinated water-soluble contrast agents (iopamidol, iohexol and Na-meglumine ioxaglate) (Konrádová et al. 1990, 1995). The administration of iopamidol caused only mild damage to the tracheal epithelium, while the degree of injury of this epithelium due to administration of other two agents was classified as moderate to severe. After iopamidol administration, the regeneration was not completed in the course of two days (Konrádová et al. 1996). Recently, the light microscopic study of the rabbits' airways after iohexol tracheobronchography showed relatively severe inflammatory and even necrotic changes in the area of the mucous membrane (Thompson et al. 1997). Therefore, we decided to extend our studies and to investigate also the reaction of the epithelium in terminal bronchioles to this diagnostic procedure.

\section{Materials and Methods}

Six clinically healthy rabbits (males, body weight $1,740 \mathrm{~g}-3,800 \mathrm{~g}$ ) were used. Under general anaesthesia (ketamine $35 \mathrm{mg} / \mathrm{kg}$ and xylazine $5 \mathrm{mg} / \mathrm{kg}$ intramuscularly), we cannulated the tracheae of three of them and injected $0.5 \mathrm{ml}$ of iopamidol (N,N'-bis(2-hydroxy-1-hydroxy-methyl-ethyl)-2,4,6-triiodo-5-lactamidoisophthalamide) (IOPAMIRO 300, Bracco, Milan, Italy) into their airways under the X-ray control (Plate III., Fig. 1). The animals breathed regularly and did not show any signs of breathlessness. Forty minutes post exposure, the thorax was opened and lungs were removed. The lung better filled with the contrast agent was immediately perfused by $5 \%$ glutaraldehyde in $0.1 \mathrm{M}$ cacodylate buffer $(\mathrm{pH} 7.2)$ and one of the lobes was transversely sectioned. Tiny pieces of the tissue were collected, fixed for 90 minutes with the same fixative and then for 60 minutes with $2 \%$ $\mathrm{OsO}_{4}$ in the same buffer ( $\mathrm{pH}$ 7.4). The material was dehydrated in graded series of alcohol and embedded in a Durcupan-Epon mixture. Terminal bronchioles were localised in semithin sections stained with toluidine blue.

\section{Address for correspondence:}

MUDr. Jiři Uhlík

Institute of Histology and Embryology

2nd Medical Faculty, Charles University

$\mathrm{V}$ úvalu 84

CZ-150 06 Prague 5, Czech Republic

Phone:+420224435982

Fax: +420224435820

E-mail: Jiri.Uhlik@lfmotol.cuni.cz 
Ultrathin sections were prepared on Ultrotome Nova LKB, contrasted with uranyl acetate and lead citrate and examined in Jeol JEM 100 C electron microscope. Three untreated rabbits, in which the lungs were removed under general anaesthesia, served as controls.

For the quantitative evaluation, the total number of ciliated and Clara cells and the functional state of Clara cells were recorded in the electron microscope using a method described in our previous paper (Uhlik 1996). The absolute values were given in Tab.1. To compare the results in both experimental groups. the chi square test was used.

The experimental procedures were approved by Ethical Commission and Commission for Protection of Experimental Animals at the 2nd Medical Faculty, Charles University, Prague.

Table 1

Evaluated cells in the epithelium of terminal bronchioles (absolute values)

\begin{tabular}{|l|c|c|c|c|c|c|c|c|}
\hline & \multicolumn{4}{|c|}{ Controls } & \multicolumn{4}{c|}{ lopamidol } \\
\hline Rabbit & No.1 & No.2 & No.3 & total & No.4 & No.5 & No.6 & total \\
\hline Ciliated cells & 127 & 77 & 80 & 284 & 29 & 90 & 41 & 160 \\
\hline Clara cells & 123 & 96 & 98 & 317 & 46 & 130 & 48 & 224 \\
\hline CC with granules & 79 & 73 & 81 & 223 & 36 & 86 & 44 & 166 \\
\hline CC without granules & 44 & 23 & 17 & 84 & 10 & 44 & 4 & 58 \\
\hline
\end{tabular}

$\mathrm{CC}=$ Clara cells

\section{Results}

The ultrastructure of the epithelium of terminal bronchioles in control rabbits

Terminal bronchioles of healthy control rabbits were lined by a simple epithelium where low columnar or cuboidal ciliated cells and high columnar Clara cells almost regularly alternated. Clara cells highly protruded into the lumen of bronchioles. Their conical or dilated apical portions overlapped the surfaces of the neighbouring ciliated ones. Intercellular spaces were narrow, apical junctional complexes were well developed, no free cells were found there.

The cytoplasm of the ciliated cells was rich in mitochondria with electron-dense matrix and numerous cristae. Tiny lysosomes or larger vacuoles containing heterogenous material were often observed. Isolated cisternae of the rough endoplasmic reticulum, not very well developed Golgi complex and several transport vesicles were also noticed. The voluminous protrusions of the neighbouring Clara cells reduced the area above the ciliated cells and thus only isolated tufts of cilia were encountered on their apical surfaces.

The apical parts of the cytoplasm of Clara cells were rich in tubules of the smooth endoplasmic reticulum filled with the moderately electron dense-material. Numerous parallel cisternae of the rough endoplasmic reticulum were situated in the basal portions of the cytoplasm. Golgi complex was not very extensive. In the cytoplasm of the Clara cells also numerous mitochondria were contained. Together with the small mitochondria of the usual appearance, also large, spherical or oval ones with the less electron-dense, finely granular matrix and a few cristae were observed. In the majority of the Clara cells, oval or slightly irregular secretory granules mostly filled with highly electron-dense, homogenous content were encountered.

In the epithelium of the terminal bronchioles of healthy control rabbits, the Clara cells and the ciliated ones represented $52.7 \pm 3.6 \%$ and $47.3 \pm 3.6 \%$ of epithelial cells, respectively. In the majority of Clara cells $(73.5 \pm 9.4 \%)$, secretory granules were discovered, only in $26.5 \pm 9.4 \%$ of them the granules were not revealed (Graph 1). 
The ultrastructure of the epithelium of terminal bronchioles in rabbits 40 minutes after administration of $0.5 \mathrm{ml}$ of iopamidol

Forty minutes post exposure, the general appearance of the epithelium did not differ from that found in control rabbits. The apical junctional complexes remained intact, the intercellular spaces were not dilated (Plate III., Fig. 2).

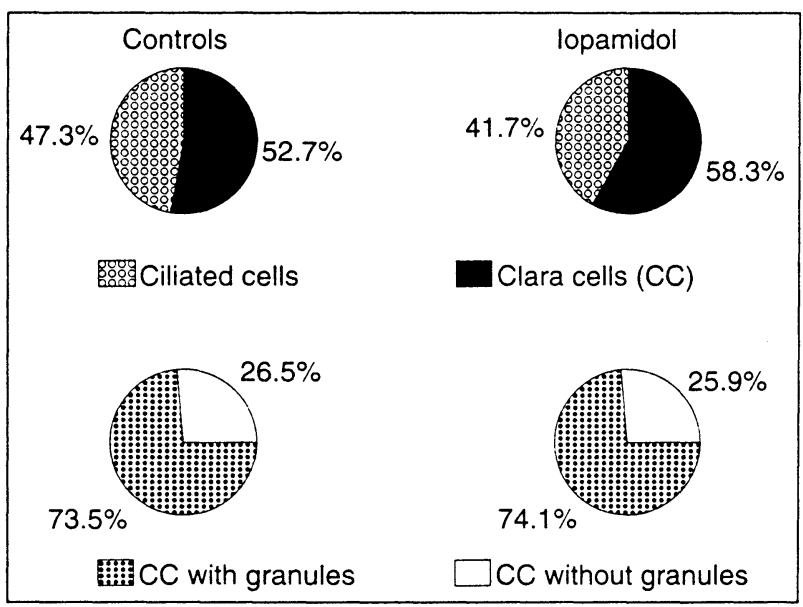

Graph 1. Quantative evaluation of the epithelium of terminal bronchioles in rabbits $40 \mathrm{~min}$ after intratracheal administration of $0.5 \mathrm{ml}$ of iopamidol.
An increased amount of small lysosomes and vacuoles was revealed mostly in the apical portions of the ciliated cells' cytoplasm (Figs. 3, 4). The mitochondria contained moderately electron-dense matrix and only a few inner cristae (Fig. 3). The Golgi complex was slightly dilated (Fig. 4). Tiny apical cytoplasmic protrusions were observed only exceptionally (Plate IV., Fig. 5). Some isolated tufts of cilia contained elements with malformed axonemes that differed in number of microtubules from the usual 9+2 arrangement (Fig. 6).

In the cytoplasm of the Clara cells, tubules of the smooth endoplasmic reticulum and spaces of the Golgi complex were slightly swollen, their content was electron-lucent (Figs. 2, 7, 8). The dilated mitochondria revealed rather lucent matrix (Fig. 7,8 ). Small electron-dense granules situated mostly beneath the apical plasma membrane did not show any signs of exocytosis (Fig. 7). On the apical surface of the Clara cells, tiny cytoplasmic protrusions exceptionally containing isolated secretory granules were found (8).

The proportion of the Clara cells to the ciliated ones was $58.3 \pm 3.8 \%$ to $41.7 \pm 3.8 \%$. The Clara cells devoid of secretory granules reached $25.9 \pm 14 \%$ (Graph 1).

\section{Discussion}

The ultrastructure of the epithelium of terminal bronchioles in various laboratory animals after administration of some substances has been described by several authors. Especially, the influence of aromatic polycyclic hydrocarbons and furans (naphthalene, 4-ipomeanol) detoxicated by the system of cytochrome P-450 monooxygenase detected in the smooth endoplasmic reticulum of Clara cells was studied. In the acute stage after parenteral administration of these substances, signs of pathological alteration of the epithelial cells or their degeneration and desquamation were observed (Plopper et al. 1992ab, 1994b; Van Winkle et al. 1995). The decrease of immunoreactivity of some enzymes from the cytochrome P-450 monooxygenase system was discovered immunohistochemically after administration of naphthalene (Lakritz et al. 1996). Some authors studied also the effect of inhalation of ozone - one of the principal photochemical pollutants - on the epithelium of airways including terminal bronchioles. In the acute phase, vacuolisation of the cytoplasm and dilatation of the smooth endoplasmic reticulum were noticed (Harkema et al. 1993; Plopper et al. 1994a). 
These findings correspond with changes in the ultrastructure of the epithelium of terminal bronchioles found shortly after the administration of iopamidol. Also in this epithelium, the appearance of numerous vacuoles, alteration of mitochondria and dilatation of the tubules of smooth endoplasmic reticulum predominate in the cytoplasm of the epithelial cells.

In our previous study describing the acute effect of the intratracheal administration of iopamidol on the ultrastructure of the tracheal epithelium, the mild degree of damage to the epithelium was accompanied by the stimulation of $43 \pm 6 \%$ of goblet cells. These cells were stimulated to release their secretion and some of them even degenerated (Konrádová et al. 1995). Nevertheless, we did not see any signs of Clara cells stimulation in the terminal bronchioles after iopamidol administration. The proportion of Clara cells containing secretory granules did not differ significantly from that found in controls. This finding corresponds to the observations of authors dealing with the effect of ozone inhalation on the airway epithelium. These authors also noticed the differences in the mild reaction of secretory cells in the terminal bronchioles and those situated in larger respiratory passages (Harkema et al. 1993; Plopper et al. 1994a).

Forty minutes after iopamidol administration, no signs of proliferation of epithelial cells were observed in the terminal bronchioles. The relative number of ciliated and Clara cells in this epithelium did not significantly differ from that in control rabbits. The extensive proliferation of Clara cells was described as a secondary reaction of the epithelium to the prolonged exposure to injurants (Harkema et al. 1993; Plopper et al. 1994a; Van Winkle et al. 1995; Lakritz et al. 1996).

Five minutes after intratracheal administration of iopamidol, the contrast agent was found as highly electron-dense needle-shaped particles in the tracheal lumen (Kon rádová et al. 1995). These particles concentrated on the membranes of epithelial cells and in areas of their highest accumulation penetrated into the cytoplasm. The penetration of the iopamidol particles in the shafts of cilia was accompanied by a destruction of their inner structure. In the terminal bronchioles, we did not find any particles 40 minutes after intratracheal administration of iopamidol.

The alteration of the epithelium of terminal bronchioles shortly after intratracheal administration of iopamidol could be a result of the transitional hypoxia caused by the filling of airways by a fluid more than of the direct effect of the contrast agent.

\section{Vliv intratracheální aplikace iopamidolu na ultrastrukturu epitelu terminálních bronchiolů králíků (Oryctolagus cuniculus var. edulis)}

Studovali jsme ultrastrukturu epitelu terminálních bronchiolů králíků 40 minut po intratracheální aplikaci jodované, vodou rozpustné kontrastní látky iopamidol. Pozorovali jsme výskyt známek patologické alterace epitelu zřejmě jako následek přechodné hypoxie $\mathrm{v}$ průběhu zákroku. Sekreční Clara buňky nebyly stimulovány k vydávání sekretu a ani známky proliferace epitelových buněk jsme nezaznamenali.

\section{Acknowledgement}

This work was supported by the Charles University grant number $79 / 97$.

\section{References}

HARKEMA, J. R., PLOPPER, C. G., HYDE, D. M., St. GEORGE, J. A., WILSON, D. W., DUNGWORTH, D. L. 1993: Response of macaque bronchiolar epithelium to ambient concentrations of ozone. Am. J. Pathol. 143: 857-866 
KONRÁDOVÁ, V., TƯMA, S., KANTA, J. 1990: The effect of Hexabrix tracheobronchography on the ultrastructure of the airway epithelium. Pediatr. Radiol. 20: 440-443

KONRÁDOVÁ, V., TƯMA, S., UHLIK, J., ZAJICOVÁ, A., ZOCOVÁ, J. 1995: Ultrastructure of the tracheal epithelium in rabbits (Oryctolagus cuniculus var. edulis) after intratracheal administration of two iodinated contrast agents. Acta Vet. Brno 64: 147-155

KONRÁDOVÁ, V., TƯMA, S., UHLÍK, J., VAJNER, L., ZAJÍCOVÁ, A., ZOCOVÁ, J. 1996: Regeneration of injury of the rabbits' (Oryctolagus cuniculus var. edulis) tracheal epithelium due to the intratracheal administration of an iodinated contrast agent. Acta Vet. Brno 65: 143-150

LAKRITZ, J., CHANG, A., WEIR, A., NISHIO, S., HYDE, D., PHILPOT, R., BUCKPITT, A., PLOPPER, C. 1996: Cellular and metabolic basis of Clara cell tolerance to multiple doses of cytochrome P450-activated cytotoxicants. I: Bronchiolar epithelial reorganization and expression of cytochrome P450 monooxygenases in mice exposed to multiple doses of naphthalene. J. Pharmacol. Exp. Ther. 278: 1408-1418

PLOPPER, C. G., MACKLIN, J., NISHIO, S. J., HYDE, D. M., BUCKPITT, A. R. 1992a: Relationship of cytochrome $\mathrm{P} 450$ activity to Clara cells cytotoxicity. III. Morphometric comparison of changes in the epithelial populations of terminal bronchioles and lobar bronchi in mice, hamsters, and rats after parenteral administration of naphthalene. Lab. Invest. 67: 553-565

PLOPPER, C. G., SUVERKROPP, C., MORIN, D., NISHIO, S., BUCKPITT, A. 1992b: Relationship of cytochrome P450 activity to Clara cell cytotoxicity. I. Histopathologic comparison of the respiratory tract of mice, rats and hamsters after parenteral administration of naphthalene. J. Pharmacol. Exp. Ther. 261: 353-363

PLOPPER, C. G., CHU, F., HASELTON, C. J., PEAKE, J., WU, J., PINKERTON, K. E. 1994a: Dose-dependent tolerance to ozone. I. Tracheobronchial epithelial reorganization in rats after 20 months' exposure. Am. J. Pathol. 144: $404-420$

PLOPPER, C. G., WEIR, A. J., NISHIO, S. J., CHANG, A., VOIT, M., PHILPOT, R. M., BUCKPITT, A. R. 1994b: Elevated susceptibility to 4-ipomeanol cytotoxicity in immature Clara cells of neonatal rabbits. J. Pharmacol. Exp. Ther. 269: 867-880

THOMPSON, I. M., WHITTLESEY, G. C., SLOVIS, T. L., CHANG, C. H., CULLEN, M. L., PHILIPPART, A. I., STOCKMANN, P. S., ADKINS, E. S., KLEIN, M. D. 1997: Evaluation of contrast media for bronchography. Pediatr. Radiol. 27: 598-605

UHLÍK, J. 1996: Quantitative evaluation of findings in the epithelium of terminal bronchioles in healthy rabbits. (Oryctolagus cuniculus var. edulis). Acta Vet. Brno 65: 181-184

Van WINKLE, L. S., BUCKPITT, A. R., NISHIO, S. J., ISAAC, J. M., PLOPPER, C. G. 1995: Cellular response in naphthalene-induced Clara cell injury and bronchiolar epithelial repair in mice. Am. J. Physiol. 269: L800L818 
Plate III.

Uhlík J., Tůma S.: Effect of... pp. 97-101.
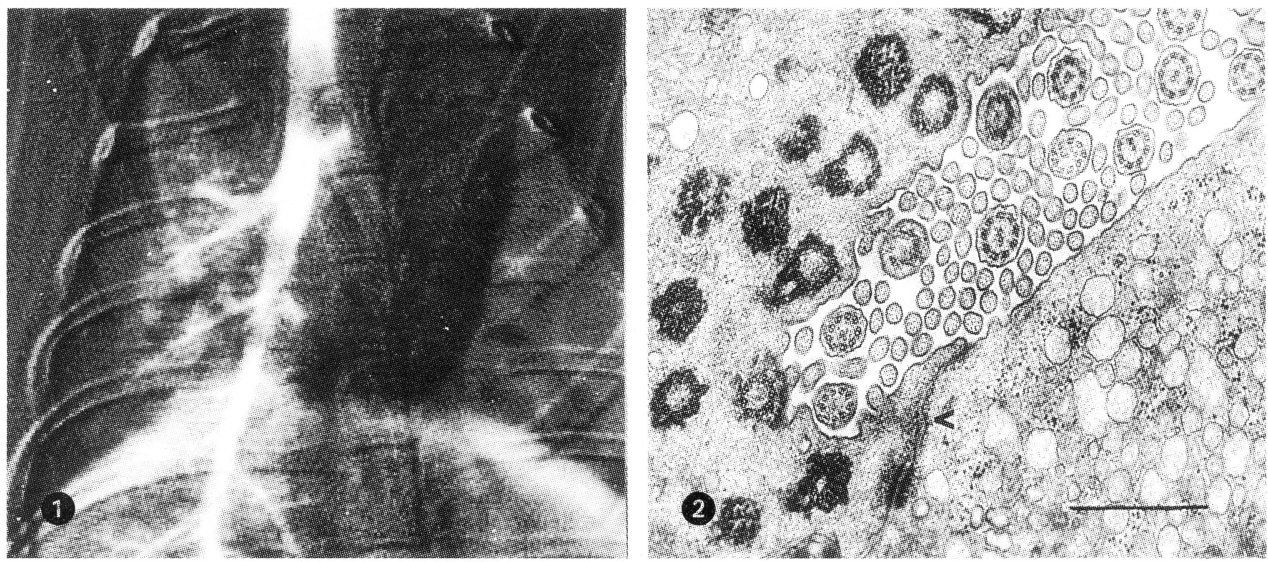

Fig. 1: Tracheobronchograph of the rabbit during intratracheal administration of $0.5 \mathrm{ml}$ of iopamidol.

Fig. 2: Intact apical junctional complex between two epithelial cells (arrowhead). The cytoplasm of the Clara cell is rich in dilated tubules of smooth endoplasmic reticulum.
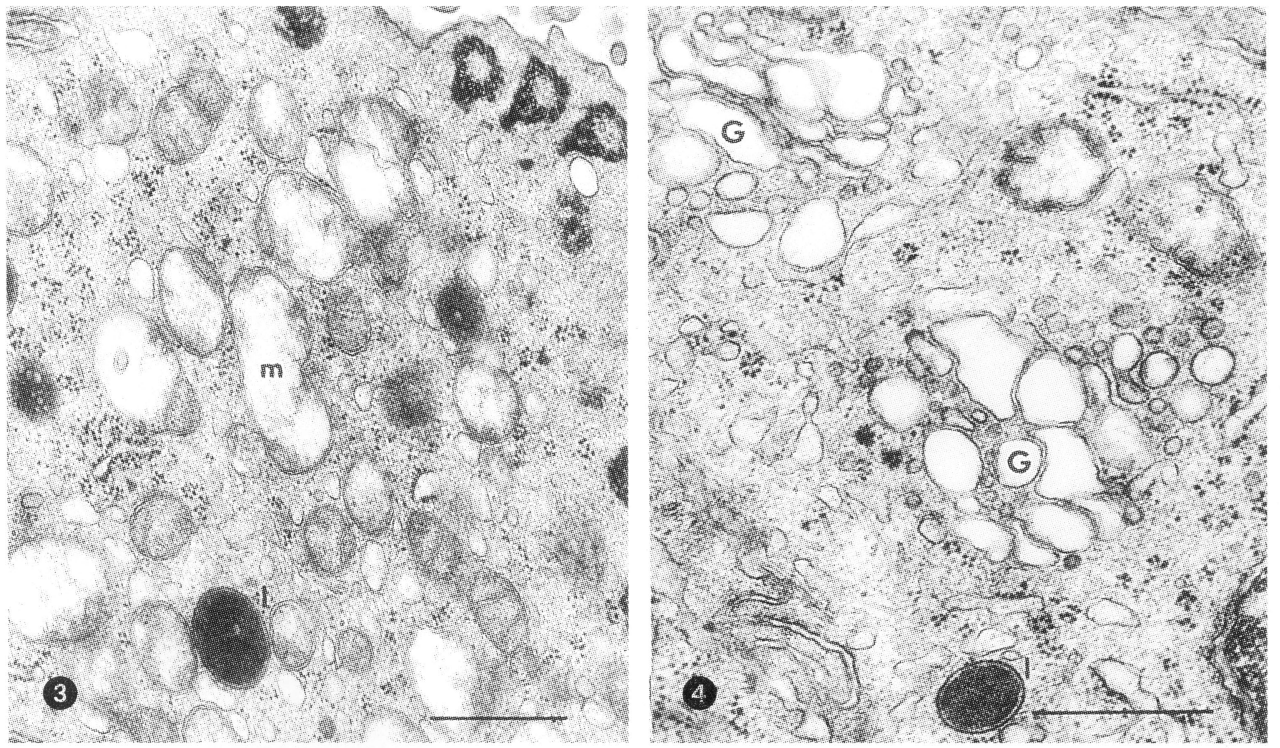

Fig. 3: Lysosome (l) and altered mitochondria (m) in the cytoplasm of the ciliated cell.

Fig. 4: Dilated Golgi complex (G) and lysosome (l) in the cytoplasm of the ciliated cell. Bars are equal to $0.5 \mu \mathrm{m}$. 

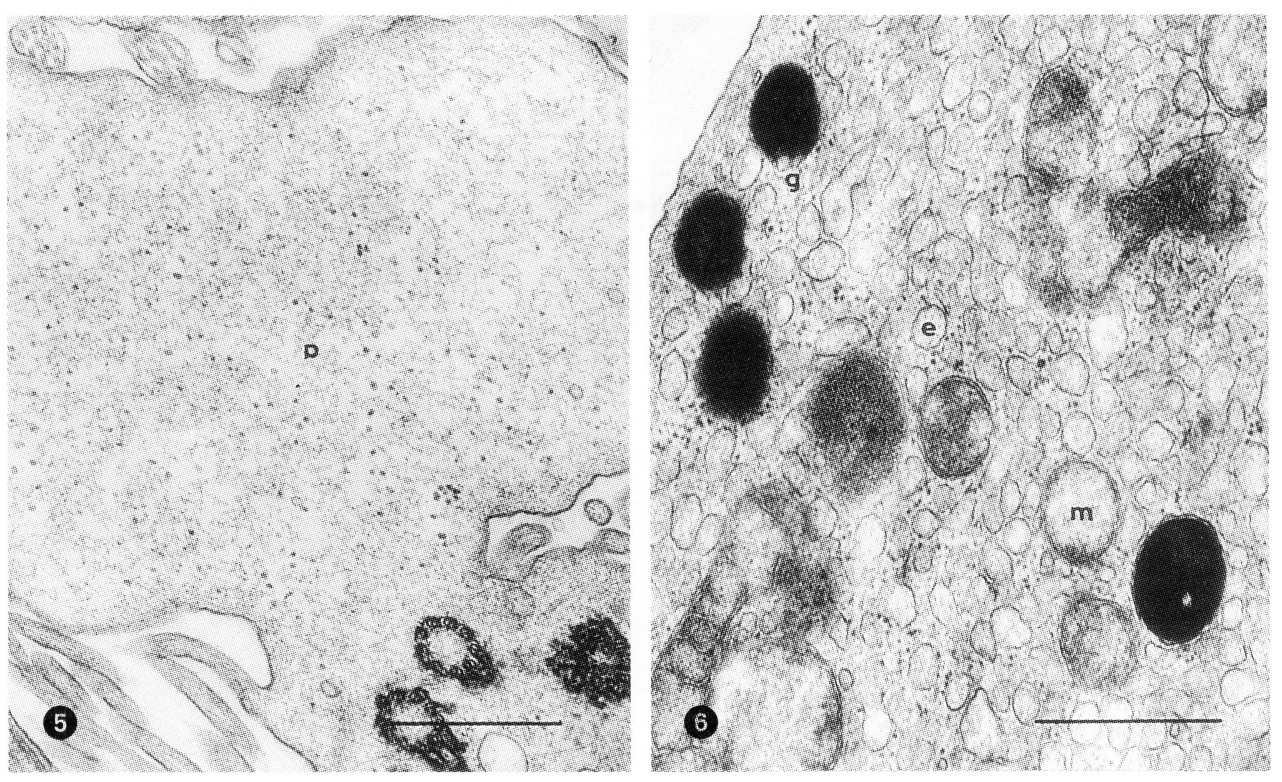

Fig. 5: Small apical cytoplasmic protrusion (p) on the surface of the ciliated cell.

Fig. 6: Slightly dilated tubules of smooth endoplasmic reticulum (e), altered mitochondria (m) and secretory granules (g) in the apical portion of the Clara cell cytoplasm.
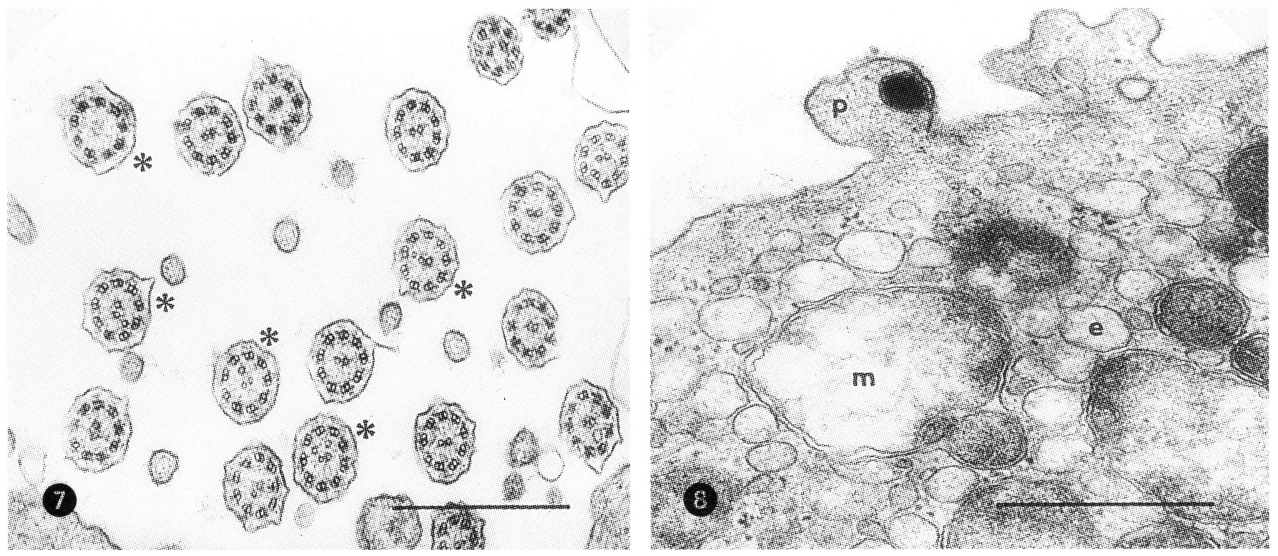

Fig. 7: Group of malformed cilia (*) above the epithelium of terminal bronchiole.

Fig. 8: Tiny apical cytoplasmic protrusion (p) with an isolated secretory granule on the apical surface of the Clara cell containing in its cytoplasm altered mitochondria $(\mathrm{m})$ and slightly dilated tubules of smooth endoplasmic reticulum (e). Bars are equal to $0.5 \mu \mathrm{m}$. 